\title{
KAJIAN TERHADAP KADAR IMUNOGLOBULIN A (IgA) SERUM YANG DIINDUKSI OLAHRAGA PADA PAGI HARI Penelitian pada Rattus novergicus (Sprague Dawley)
}

\author{
Ivonny M. Sapulete \\ Bagian Fisiologi Fakultas Kedokteran Universitas San Ratulangi Manado \\ Email: ivonnesapulete@gmail.com
}

\begin{abstract}
Immunoglobulin A (IgA) is a glycoprotein molecule which is produced by plasma cells. It functions as an antibody and the first line defender towards assorted pathogens that get into the body. Physical exercise is influenced by circardian rhythm. This circardian rhythm causes physiological changes in the body including the immune system. Doing physical exercise in the morning decreases the level of IgA serum due to the increase of cortisol hormone. IgA secretion is influenced by physical exercise which depends on the intensity, time of duration, and type of physical exercise. The physical exercise of medium intensity increases glutamine production due to glutaminase enzyme causing proliferation of $\mathrm{T}$ and $\mathrm{B}$ lymphocytes. These B lymphocytes secrete IgA resulting in the increase of immune system. However, the physical exercise of heavy intensity degrades the production of glutamine, therefore, lymphocyte proliferation decreases resulting in the decrease of IgA secretion. This decrease of IgA secretion is caused by the existence of stress, cortisol hormone, and oxidative stress. Conclusion: Regular physical exercise of medium intensity can prevent the decrease of IgA serum level in Rattus Novergicus (Sprague Dawley) rats in the morning.
\end{abstract}

Keywords: physical exercise, IgA

\begin{abstract}
Abstrak: Imunoglobulin A (IgA) adalah molekul glikoprotein yang dihasilkan oleh sel plasma yang berfungsi sebagai antibodi dan garis pertahanan pertama terhadap berbagai macam patogen yang masuk ke dalam tubuh. Olahraga dipengaruhi oleh irama sirkardian. Irama sirkardian ini menyebabkan perubahan dalam tubuh termasuk sistem kekebalan. Olahraga pada pagi hari menurunkan kadar IgA serum karena adanya peningkatan hormon korisol. Sekresi IgA dipengaruhi oleh olahraga yang tergantung dari intensitas, durasi dan jenis olahraga. Penelitian ini bertujuan untuk mendapatkan gambaran kadar IgA setelah olahraga intensitas sedang dan berat. Penelitian ini bersifat eksperimental murni dengan pre post control group design. Sampel yang digunakan ialah 15 ekor Rattus novergicus (Sprague Dawley) berjenis kelamin jantan, usia 12 minggu, dan berat badan 200-300g. Sampel dibagi atas 3 kelompok: kelompok kontrol (K1), kelompok olahraga intensitas sedang (K2), dan kelompok olahraga intensitas berat (K3). Hasil penelitian memperlihatkan selisih kadar IgA (\%) setelah olahraga terbesar pada K1 $(-15,8 \pm 6,3)$, diikuti oleh K3 $(-12,5 \pm 18,7)$, dan K2 ($2,2 \pm 26,2)$. Simpulan: Olahraga teratur intensitas sedang dapat mengurangi penurunan kadar IgA serum tikus Rattus novergicus (Sprague Dawley) pada pagi hari.
\end{abstract}

Kata kunci: olahraga, IgA

Olahraga sangat penting dalam mempertahankan kebugaran dan kesehatan, meningkatkan metabolisme, meningkatkan sistem kekebalan tubuh, serta mengurangi stres sehingga tubuh dapat terhindar dari berbagai macam penyakit. ${ }^{1}$ Prinsip olahraga dikenal dengan FITT yaitu frequency, intensity, time, and type. 
Frekuensi mencakup berapa kali olahraga itu dilakukan; intensitas tergantung pada ringan, sedang, dan beratnya olahraga; durasi memberi gambaran lamanya waktu olahraga; dan jenis atau tipe olahraga. ${ }^{2}$

Imunoglobulin A (IgA) adalah molekul glikoprotein yang dihasilkan oleh sel plasma dan berfungsi sebagai antibodi, serta terdiri atas imunoglobulin yang terdapat dalam serum dan mukosa. Dalam bentuk sekresinya IgA merupakan garis pertahanan pertama terhadap berbagai macam patogen yang masuk dalam tubuh. ${ }^{3,4}$ Sekresi IgA dapat dirangsang oleh aktivitas fisik, tergantung dari intensitas dan durasi latihan serta jenis aktivitas fisik. $^{5}$

Olahraga berhubungan dengan sistem kekebalan dan dipengaruhi oleh glutamin yang berfungsi sebagai link metabolism., Peningkatan produksi glutamin, akan diikuti oleh peningkatan proliferasi limfosit termasuk limfosit $\mathrm{T}$ dan B. Limfosit $\mathrm{B}$ kemudian akan menyekresikan IgA. ${ }^{8}$ Olahraga dengan intensitas berat dan berkepanjangan akan menurunkan konsentrasi glutamin yang mengakibatkan penurunan sekresi IgA. ${ }^{4}$ Selain itu, penurunan sekresi IgA dapat disebabkan oleh sekresi hormon kortisol dan terjadinya stres oksidatif.;

\section{METODE PENELITIAN}

Penelitian ini bersifat eksperimental murni dengan rancangan percobaan pre post control group design. Sampel yang digunakan ialah Rattus novergicus (Sprague Dawley) berjenis kelamin jantan, usia 12 minggu, berat badan 200-300g sebanyak 15 ekor. Sampel dibagi atas 3 kelompok: kelompok kontrol (K1), kelompok olahraga intensitas sedang (K2), dan kelompok olahraga intensitas berat (K3). Penelitian berlangsung selama 63 hari. Variabel penelitian ialah kadar IgA serum.

\section{HASIL DAN BAHASAN.}

Hasil analisis kadar IgA serum pada setiap kelompok menunjukkan data terdistribusi normal. Ada tidaknya perbedaan perubahan kadar IgA serum tikus sebelum dan sesudah olahraga dianalisis dengan uji Paired T Test. Hasil pemeriksaan kadar IgA serum dapat dilihat pada Tabel 1.

Tabel 1. Rerata hasil pengukuran kadar IgA serum (\%) pada kelompok normal (K1), kelompok olahraga intensitas sedang (K2), dan kelompok olahraga intensitas berat (K3).

\begin{tabular}{cccc}
\hline Kelompok & \multicolumn{2}{c}{ Rerata IgA (\%) } & $P$ \\
& Pretest & Post test & \\
\hline K1 & 100 & 84,1 & 0,06 \\
K2 & 100 & 97,7 & 0,93 \\
K3 & 100 & 87,4 & 0,53 \\
\hline
\end{tabular}

Tabel 2. Rerata hasil pengukuran selisih kadar IgA serum (\%) uji One Way Anova pada kelompok normal (K1), kelompok olahraga intensitas sedang (K2), kelompok olahraga intensitas berat (K3).

\begin{tabular}{cccc}
\hline & Kelompok & Rerata \pm SEM $(\%)$ & $P$ \\
\hline Kadar IgA & K1 & $-15,8 \pm 6,3$ & 0,87 \\
serum & K2 & $-2,2 \pm 26,2$ & \\
& K3 & $-12,5 \pm 18,7$ & \\
\hline
\end{tabular}

Penurunan kadar IgA serum tikus kelompok K2 mungkin disebabkan tikus mengalami stres ketika diberi perlakuan olahraga. Penelitian untuk prosedur 
olahraga intensitas sedang ini hampir sama dengan yang dilakukan oleh Moraska et al. ${ }^{10}$ yang meneliti olahraga treadmill pada tikus jantan Sprague Dawley selama 8 minggu durasi 60 menit, dan menunjukkan adanya stres pada tikus. Demikian pula hasil penelitian Dimitriou et al. ${ }^{11}$ bahwa kadar IgA pada olahraga tidak dipengaruhi oleh intensitas dan durasi latihan tetapi dipengaruhi oleh irama sirkardian. Olahraga treadmill pada tikus kadang dapat menginduksi terjadinya stres. Stres pada tikus mungkin juga disebabkan oleh perlakuan treadmill pada pagi hari. Perbedaan waktu olahraga pada tikus akan mengganggu ritme biologis tikus tersebut sehingga tikus mengalami stres yang menyebabkan penurunan proliferasi limfosit dan penurunan kadar IgA serum. $^{12,13}$

Olahraga dipengaruhi oleh irama sirkardian. Olahraga pada pagi hari bisa meningkatkan kerentanan terhadap infeksi virus dengan terjadinya penurunan kadar IgA karena adanya peningkatan hormon kortisol. ${ }^{11}$ Hal yang sama dilaporkan oleh Lee dan Gleeson ${ }^{14}$ bahwa IgA meningkat pada malam hari. Peningkatan hormon kortisol pada pagi hari akan menekan produksi IgA. Irama sirkardian menyebabkan perubahan fisiologis dalam tubuh termasuk sistem kekebalan. Irama sirkardian dalam tubuh dipengaruhi oleh hormon melatonin yang disekresikan oleh kelenjar pineal yang berperan sebagai imunomodulator. $^{15}$

Pada penelitian ini tikus yang diberi perlakuan olahraga intensitas berat mengalami penurunan kadar IgA serum meskipun secara statistik tidak berbeda bermakna. Penurunan kadar IgA dikarenakan adanya peningkatan sekresi hormon kortisol yang disebabkan oleh rangsangan hipotalamus sehingga kelenjar adrenal menyekresikan hormon kortisol. ${ }^{16}$ Peningkatan hormon kortisol disebabkan juga oleh adanya sitokin proinflamasi yaitu IL6 sehingga terjadi penurunan proliferasi limfosit dan sekresi limfosit B. ${ }^{17}$

$$
\text { Latihan berat menyebabkan }
$$
peningkatan kebutuhan oksigen 15 kali lipat untuk pembentukan ATP. Persediaan ATP sangat terbatas sehingga jika terjadi peningkatan kebutuhan ATP, maka ATP akan terus diproduksi melalui proses oksidasi. Mitokondria merupakan tempat pembentukan energi/ATP. Pada latihan berat terjadi peningkatan aktifitas transpor elektron dalam mitokondria. Bila transpor elektron berjalan kurang baik maka akan terbentuk superoksid. ${ }^{9}$

Pada penelitian ini secara keseluruhan ketiga kelompok tikus menunjukkan penurunan kadar IgA serum terutama kelompok kontrol. Hal ini kemungkinan disebabkan oleh adanya perubahan berat badan. Penurunan berat badan dapat diakibatkan oleh terjadinya stres yang menyebabkan menurunnya nafsu makan pada tikus. Moazzam et al. ${ }^{18}$ melaporkan tikus Sprague jantan mengalami penurunan berat badan akibat stres yang memengaruhi kadar IgA. Hal ini serupa dengan penelitian Moraska et al. ${ }^{10}$ yang melaporkan bahwa tikus Sprague Dawley dengan perlakuan olahraga treadmill selama 8 minggu mengalami penurunan berat badan.

\section{SIMPULAN}

Olahraga teratur intensitas sedang dan berat dapat mengurangi penurunan kadar IgA serum pada tikus Rattus novergicus (Sprague Dawley) pada pagi hari.

\section{SARAN}

Perlu dilakukan penelitian tentang hubungan olahraga teratur intensitas sedang dan berat pada imunoglobulin yang lain, kortisol, dan IL6.

\section{DAFTAR PUSTAKA}

1. Barker J. Immunology, nutrition and the athlete Part I. 2012. [cited 2013 April 2]. Available from: http://www.Drjasonbarker./immunolog y.com/articles/putonwebsite/immunolo gy, nutrition and the athlete.pdf.

2. Stephens MB. Exercise prescription. O’Connor FG, Sallis RE, Wilder RP, Pierre PS (editors). Sports Medicine: Just the Facts. New York: McGraw Hill, 2005. 
3. Mayer G. Imunoglobulins structure and function. Microbiology and Immunology Online. Columbia: University of South Carolina School of Medicine, 2009.

4. Nieman DC. Exercise and immune function: Nutritional influence. 2005. [cited 2010 Nov 21]. Available from: http://www.ker.com/library/advance/32 0 .pdf.

5. Trochimiak T, Wozniak EH. Effects of exercise on the level of immunoglobulin A in saliva. Biology of Sport. 2012;29(4):255-61.

6. Natale VM, Shepard RJ. Interrelationship between acute and chronic exercise and the immune and endocrine system. Sports Endocrinology. 2000;23:281301.

7. Kuhn KS, Schuhmann K, Stehle P, Darmaun D, Furst P. Determination of glutamine in muscle protein facilitates accurate assessment of proteolysis and the novo synthesis derived endogenous glutamine production. The American Journal of Clinical Nutrition. 1999;70(4):484-9.

8. Waddell D, Frederick $K$. Effect of a glutamin suplement on the skeletal muscle contractile force of mice. American Journal of Undergraduate Research. 2005;4(2):11-18.

9. Wellman KF, Bloomer RJ. Acute exercise and oxidative stress a 30 years history. Dynamic Medicine. 2009;8(1):1-25.

10. Moraska A, Deak T, Spencer RL, Roth $\mathbf{D}$, Flashner $\mathbf{M}$. Treadmill running produced both positive and negative physiological adaptation in Sparague Dawley Rats. American Journal of Physiology. Regulatory Intergative and Comparative 2000;279:1321-9.

11. Dimitriou L, Sharp NC, Doherthy $M$. Circardian effects on the acute responses of salivary cortisol and IgA in well trained swimmers. British Journal Sports of Medicine. 2002;36:260-4.

12. Nomura S. Salivary hormones, immunes and other secretory substances as possible stress biomarker. Biomarker. 2012;(2):247-70.

13. Rodriguez RC, Victoria MG, Rojano EA, Yepez JP, Garfias HR, Cabrera RE, et al. Stress modulates intestinal secretory immunoglobulin A. Frontiers in integrative neuroscience. 2013;7(86).

14. Lee TL, Gleeson M. The effect of single and repeated bouts of prolonged cycling and circadian variation on saliva flow rate, immunoglobulin A and alphaamylase responses. Journal Sports Science. 2004;22(11-12):1015-24.

15. Amirahmadi M, Shafiri G, Salesi M, Haidarnia E. An investigation on effect of diurnal variation and type of activity on hormonal immune's indexes in elite male swimmers. 2014. [cited 2014 Aug 7]. Available from:http://ijjsjournal.com/wpContent/2014/07/peaper.pdf.

16. Victoria MG, Serrano ED, Garfias HR, Viloria M, Padilla EL, Albor AA, et al. Effects on secretory IgA levels in small intestine of mice that underwent moderate exercise trainning followed by about of strenous swimming exercise. Brain, Behavior and Immunity. 2012;26(8):1300-9.

17. Pedersen BK, Goetz LH. Exercise and the immune system: regulation, integration and adaptation. Physiological review. 2000;80(3):1055-82.

18. Moazzam S, Hossain, MM, Babar A. Response of hypothalamo pituitary adrenal axix and immune system to chronic restraint stress in male Sprague Dawley rats. Pakistan Journal. 2013; 9(1):29-31. 